\title{
Prevalence of Obesity among Adolescents in Senior Secondary Schools in Oyo State, Nigeria
}

\author{
AR Akinlade ${ }^{1 *}$, WAO Afolabi ${ }^{1}$, EB Oguntona ${ }^{1}$ and Mure Agbonlahor ${ }^{2}$ \\ ${ }^{1}$ Nutrition and Dietetics Department, Federal University of Agriculture, Ogun State, Nigeria \\ ${ }^{2}$ Agricultural Economics and Farm Management, Federal University of Agriculture, Ogun State, Nigeria
}

Received: August 04, 2014; Accepted: October 23, 2014; Published: November 13, 2014

*Corresponding author: Ademola Akinlade, Nutrition and Dietetics Department, Federal University of Agriculture, Ogun State, Nigeria, Tel: +2348030744268; E-mail: ademola.rich@gmail.com

\begin{abstract}
This study was carried out to examine the prevalence of obesity among adolescents in Oyo state. A total of 821 [male (383) and female (438)] aged 12-18 years were selected from 10 public and private secondary schools using multi-stage sampling techniques. Data collected were subjected to descriptive statistics. Results showed that majority $(73.3 \%)$ of the respondents were between $15-18$ years. Prevalence of obesity among the respondents using BMI-for-Age percentile shows that majority $(82.5 \%)$ of the respondents were between 5 th-85th percentiles (normal), $2.2 \%$ were between 85 th95th percentiles (overweight), while $2.6 \%$ percentile were above 95th percentile (obese). Both sexes show a significant difference (P $\leq 0.05$ ) in anthropometric measurement [height, body mass index (BMI-for-Age), triceps, biceps, waist circumference, hip circumference and percentage body fat]. Therefore, the study concluded that the prevalence of obesity among adolescents is relatively low and highlights the need for larger population-based studies to ascertain the overall prevalence within the state.
\end{abstract}

Keywords: Obesity; Overweight; Adolescent; Nutrient Intake; BMI-for-Age; Body Fat

\section{Introduction}

Obesity is quickly becoming one of the most prominent conditions affecting children and adolescents [1]. Adolescents are nutritionally vulnerable age group, considering their increased nutritional needs, eating patterns, life style and susceptibility to environmental influences [2,3]. Overweight and obesity is an escalating health problem in both developed and developing countries. The International Obesity Task Force report showed that 1 in 10 children worldwide is overweight; a total of 155 million children and adolescents are overweight and around 3045 million are classified as obese [4].

The prevalence of obesity has increased substantially over the last few decades and indications are that this trend will continue [5]. In Nigeria, there is a dearth of data on the prevalence of overweight and obesity. A study by Omolola et al. [6] in south western Nigeria reported no adolescent to be neither overweight nor obese among the rural dwellers studied. Another study in
Lagos, Nigeria Ben-Bassey et al. [7] reported overall prevalence rates of overweight and obesity in the urban and rural areas to be $3.7 \%$ and $0.4 \%$, and $3.0 \%$ and $0.0 \%$, respectively. Furthermore, the prevalence rates of obesity and being overweight in a study carried out in Cross River, Nigeria were 1.7\% and 6.8\%, respectively [8].

Considering the importance of obesity complications for the health state of society and its increasing rate, careful evaluation, monitoring and follow up of obesity in children and adolescents should be a great importance. Therefore, the aim of this study was to find the prevalence of obesity in Nigerian adolescents in an urban community.

\section{Subjects and Methods}

\section{Subject and sample size}

The subjects were urban adolescent attending Senior Secondary School Children in the age group of 12-18 years in Oyo State, Nigeria. Subjects were selected from Government and Private schools, in order to recruit them from different socioeconomic strata. Total sample size was 821 respondents from both public (447) and private (375) Schools in the selected Local Government Areas.

\section{Methodology}

The study was descriptive and cross-sectional covering public and private secondary schools in Ibadan North and Ibadan SouthWest Local Government Areas of Oyo State. Data was collected during 2011/2012 academic session (second term).

\section{Sampling procedure}

The samples for this study were drawn from 20 public and private secondary schools within the two selected local government area (Ibadan North and Ibadan South-West) of Oyo State, Nigeria. The schools were randomly selected from a list of all the schools in the local government areas. Twenty schools were the targeted study sample. Respondents were selected using multistage sampling techniques. Both boys and girls were eligible to participate in the study. 


\section{Method of data collection}

The data was collected using a validated structured sectionalized questionnaire. The questionnaire has information on (personal data, socio-economic and demographic, physical activities, dietary and food intake pattern, anthropometric measurement, 24-hour dietary recall and food frequency). Questionnaire written in English was administered to the selected adolescents from each of the selected class and the subjects were requested to record their responses in the presence of investigators, who provided necessary clarification to the queries, if any, in a classroom

\section{Equipment and tools for data collection}

Portable anthropometric heightiometer was used to measure height of the adolescents and digital OMRON Body Composition (BF 508) was used to measure the weight (Kg) and body fat (\%). Harpenden skinfold calliper was used to measure skinfold ( $\mathrm{mm}$ ). Waist and hip circumferences were measured using non-elastic fibre measuring tapes to the nearest $\mathrm{cm}$.

\section{Data analysis}

The data was cleaned, and then entered into the computer, for analysis using SPSS, version 16.0 and Epi Info (TM) 3.5.1. The data generated were analyzed using descriptive statistics such as means, standard deviations, percentages and frequencies of participant's characteristics anthropometrical tests measurements were computed and provided for each age and gender. The differences between male and female adolescents were determined using students t-test.

\section{Results}

\section{Socioeconomic characteristics of the respondents}

Female respondents constituted the highest percentage being $53.3 \%$ while male constituted $46.7 \%$. Respondent's age were between 12-18years, 12-14 year old respondents had least percentage $26.7 \%$ while $15-18$ year old were $73.3 \%$. Socioeconomic status revealed that majority of the respondent's parent $75.2 \%$ belong to the middle socioeconomic status (MSES) while $11.0 \%$ and $13.9 \%$ belongs to low (LSES) and high (HSES) socioeconomic status. Also, $12.5 \%$ of the respondents went to school through public transport and parent's car, $39.2 \%$ went to school with public transport while $14.9 \%$ trek to school (Table 1).

Anthropometric and body composition: The respondents showed that except, for weight and waist-hip ratio (WHR), all other anthropometric and body composition variables were significantly different in both sexes $(\mathrm{p} \leq 0.05)$. The mean values for height, Body Mass Index (BMI), triceps, biceps, waist circumference, hip circumference, percentage body fat, were significantly higher in girls compared to the boys. There is no significant difference between the mean Weight and Waist-Hip Ratio (WHR) of the boys and girls (Table 2).

Prevalence of Obesity (Body Mass Index for Age Percentile): Majority of the respondents $82.5 \%$ were between $5^{\text {th }}-85^{\text {th }}$ percentiles, $2.2 \%$ were between $85^{\text {th }}-95^{\text {th }}$ percentiles,
Table 1: Socioeconomic Characteristics of the Respondents.

\begin{tabular}{|c|c|c|}
\hline & Frequency & Percentage \\
\hline \multicolumn{3}{|l|}{ Sex } \\
\hline Male & 383 & 46.7 \\
\hline Female & 438 & 53.3 \\
\hline Total & 821 & 100.0 \\
\hline \multicolumn{3}{|l|}{ Age } \\
\hline $12-14$ & 219 & 26.7 \\
\hline $15-18$ & 602 & 73.3 \\
\hline Total & 821 & 100.0 \\
\hline \multicolumn{3}{|c|}{ Education level of Father } \\
\hline No education & 5 & 0.6 \\
\hline Primary education & 60 & 7.3 \\
\hline Secondary education & 266 & 32.4 \\
\hline Tertiary education & 490 & 59.7 \\
\hline Total & 821 & 100.0 \\
\hline \multicolumn{3}{|c|}{ Education level of Mother } \\
\hline No education & 18 & 2.2 \\
\hline Primary education & 72 & 8.8 \\
\hline Secondary education & 262 & 31.9 \\
\hline Tertiary education & 496 & 57.1 \\
\hline Total & 821 & 100.0 \\
\hline \multicolumn{3}{|l|}{ Occupation of Father } \\
\hline Civil servant & 240 & 29.2 \\
\hline Lecturer & 21 & 2.6 \\
\hline Personal business & 364 & 44.3 \\
\hline Teacher & 141 & 17.2 \\
\hline $\begin{array}{l}\text { Employee of private } \\
\text { organization }\end{array}$ & 55 & 6.7 \\
\hline Total & 821 & 100.0 \\
\hline \multicolumn{3}{|l|}{ Occupation of Mother } \\
\hline Civil servant & 211 & 25.7 \\
\hline Lecturer & 15 & 1.8 \\
\hline Personal business & 463 & 56.4 \\
\hline Teacher & 110 & 13.4 \\
\hline $\begin{array}{l}\text { Employee of private } \\
\text { organization }\end{array}$ & 22 & 2.7 \\
\hline Total & 821 & 100.0 \\
\hline \multicolumn{3}{|c|}{ How do you get to school } \\
\hline School bus & 27 & 3.3 \\
\hline Parent's car & 247 & 30.1 \\
\hline Public transport & 322 & 39.2 \\
\hline Trekking & 122 & 14.9 \\
\hline $\begin{array}{l}\text { Parent's car \& public } \\
\text { transport }\end{array}$ & 103 & 12.5 \\
\hline Total & 821 & 100.0 \\
\hline \multicolumn{3}{|l|}{ Socioeconomic Status } \\
\hline LSES & 90 & 10.9 \\
\hline MSES & 617 & 75.2 \\
\hline HSES & 114 & 13.9 \\
\hline Total & 821 & 100.0 \\
\hline
\end{tabular}

.


Table 2: Anthropometric Characteristics of the Respondents.

\begin{tabular}{|l|c|c|c|c|}
\hline Variable & Male (n=383) (Mean $\mathbf{\text { SD}})$ & Female (n=438) (Mean \pm SD) & t-value & p-value \\
\hline Weight $(\mathrm{kg})$ & $52.18 \pm 9.16$ & $51.47 \pm 8.95$ & 1.111 & 0.267 \\
\hline Height $(\mathrm{cm})$ & $162.13 \pm 8.45$ & $158.17 \pm 6.66$ & 7.504 & $0.000^{*}$ \\
\hline BMI $\left(\mathrm{kg} / \mathrm{m}^{2}\right)$ & $19.75 \pm 2.71$ & $20.51 \pm 3.11$ & -3.750 & $0.000^{*}$ \\
\hline Triceps $(\mathrm{mm})$ & $5.92 \pm 3.63$ & $8.73 \pm 4.45$ & -9.823 & $0.000^{*}$ \\
\hline Biceps $(\mathrm{mm})$ & $4.49 \pm 3.97$ & $5.45 \pm 4.05$ & -3.428 & $0.001^{*}$ \\
\hline Waist $(\mathrm{cm})$ & $69.05 \pm 6.36$ & $70.52 \pm 7.06$ & -3.106 & $0.002^{*}$ \\
\hline Hip (cm) & $84.76 \pm 8.01$ & $86.67 \pm 7.85$ & -3.437 & $0.001^{*}$ \\
\hline WHR (cm) & $0.82 \pm 0.10$ & $0.81 \pm 0.10$ & 0.672 & 0.502 \\
\hline Body fat $(\%)$ & $14.98 \pm 7.96$ & $23.20 \pm 7.77$ & -14.953 & $0.000^{*}$ \\
\hline
\end{tabular}

*Statistically significant $(\mathrm{p} \leq 0.05)$

Table 3: Prevalence of Obesity (Body Mass Index for Age Percentile).

\begin{tabular}{|l|l|l|}
\hline & Frequency & percentage \\
\hline Underweight & 105 & 12.8 \\
\hline Normal & 677 & 82.5 \\
\hline Overweight & 18 & 2.2 \\
\hline Obese & 21 & 2.6 \\
\hline Total & 821 & 100.0 \\
\hline
\end{tabular}

Table 4: Mean Nutrient Intake of Respondents (Male and Female).

\begin{tabular}{|c|c|c|}
\hline NUTRIENT & RANGE & MEAN \pm SD \\
\hline Calorie (kcal) & $1039.98-2197.00$ & $1726.82 \pm 327.45$ \\
\hline Protein (g) & $10.96-57.78$ & $39.32 \pm 10.74$ \\
\hline Carbohydrate (g) & $89.80-294.00$ & $170.61 \pm 56.49$ \\
\hline Fiber (g) & $0.00-68.94$ & $13.07 \pm 10.69$ \\
\hline Fat (g) & $1.22-54.21$ & $29.90 \pm 14.07$ \\
\hline Vitamin A (RE) & $19.55-978.89$ & $478.42 \pm 293.74$ \\
\hline Vitamin C (mg) & $0.00-89.90$ & $7.18 \pm 5.70$ \\
\hline Folate (mcg) & $0.00-642.10$ & $136.61 \pm 118.14$ \\
\hline Vitamin B12 (mcg) & $0.00-6.38$ & $1.42 \pm 1.15$ \\
\hline Calcium (mg) & $27.00-885.72$ & $305.25 \pm 216.17$ \\
\hline Zinc (mg) & $0.01-15.88$ & $6.88 \pm 2.96$ \\
\hline Iron & $3.2-21.1$ & $11.31 \pm 4.70$ \\
\hline
\end{tabular}

$2.6 \%$ were below $5^{\text {th }}$ percentile while $2.6 \%$ percentile were above $95^{\text {th }}$ percentile. Prevalence of obesity among male and female were $0.8 \%$ and $1.8 \%$. Female overweight was $2.2 \%$ (Table 3 ).

Mean nutrient intake of respondents: In the energy section, the mean value of both female and male $1685.69 \pm 302 \mathrm{kcal}$ and $1767.96 \pm 349.25 \mathrm{kcal}$ were less than the RDA by $23.38 \%$. Carbohydrate mean intakes of the respondents were above the RDA by $126.98 \%$ and $135.50 \%$ for both female and male, while Fat, Iron and Zinc mean intakes were within RDA. Mean intake of Protein, Vitamin A, vitamin C, Vitamin $B_{12}$, Folate, and Calcium were below recommended daily allowance for male and female while mean intake of Fat, Iron and Zinc were within RDA for both sex (Table 3).

\section{Discussion}

The study sought to assess prevalence of obesity among adolescents in secondary schools by determining socio-economic, demographic, anthropometric, dietary and nutrient intake.

Body mass and height are the most important measures of growth, development and reflect health condition and maturity of an individual [9]. The finding that body mass and stature increase with increasing age is consistent with biological processes in adequately nourished children [10]. Among public and private school respondents male were heavier and taller than female with no significant difference between male and female weight. Height shows significant difference between the male and female. 
In contrast to the study of Mantsena et al. [11] reported boys as having significantly higher body mass and increased stature in a study conducted on rural South African school children aged 5 to 14 years. Similarly, the stature of Nigerian children in this study was comparable with Senegalese children aged 10 to 13 years [12], however, the body mass of the participants in the study by Benefice and Ndiaye was lower compared to Nigerian children in the present study.

Body mass index changes with growth from infancy through childhood to adolescence [13]. BMI demonstrated significant sex differences with high mean values in girls. This finding is in contrast with the [14] Monyeki et al. study, which found nonsignificant differences in BMI in South African rural primary school children. However, the BMI values obtained from Monyeki et al. [14] study were lower than the BMI values in this study. With the use of boundary BMI values calculated by [15], the percentage of overweight and obesity of respondents was calculated in the group of respondents examined. Obesity $2.6 \%$, Overweight $2.2 \%$. BMI-for-age however, might not necessarily be appropriate in suggesting that so many of this study's children are largely exempt from overweight or obesity. The BMI values may actually be misleading due to the body proportions of these children. Pawloski et al. [16] have reported that little is known regarding specific BMI values in adolescence and their relationships with concurrent or future risks and that the BMI-for-age curves do not necessarily 'provide a desirable pattern that should be used as a healthy goal for adolescents internationally'.

The finding that waist circumference and hip circumference increased more in male than in female with significant difference between male and female. The sex difference in waist circumference is unclear, in that it may be that levels of physical activity are less in girls than in the boys, as research have suggested that waist circumference has stronger associations with physical activity in young people [17]. Waist circumference increased with age is consistent with the literature, since during puberty, males deposit adipose tissue around the upper body whilst females deposit adipose tissue around the thighs and buttocks due to the production of sex hormones of oestrogen and testosterone in females and males, respectively [18]. Waist-hip ratio shows no significant difference between male and female

\section{Conclusion and Recommendation}

The prevalence of obesity among adolescents in secondary schools in Oyo State is lower than those found in the literature. The actual prevalence of obesity is low. The prevalence of obesity is highest among females who are within the age group of 15 - 18 years. Technology has contributed many wonderful conveniences in our society but at the expense of creating a remarkably sedentary lifestyle with no end in sight. It is all up to us to make our children more physically active and in many ways develop in them the idea to choose more properly the kind of food they eat.

Parents should make time for the family to engage in sports activities and other regular physical activities like walking or hiking, swimming, and bicycling. Also, they must encourage their children to perform household chores that will make them more physically active. Schools must provide opportunities for daily physical education and comprehensive health education. PE classes should incorporate aerobic exercises and recreational activities.

\section{References}

1. Chen MY, Chou CC, Yang RJ. Considering the factors of gender and body weight in the promotion of healthy behavior among adolescents. J Nurs Res. 2005; 13(3):235-43.

2. World Health Organization. Nutrition in adolescence: issues for the health sector: issues in adolescent health and development. Available from: http://whqlibdoc.who.int/publications/2005/9241593660_ eng.pdf.

3. World Health Organization. Preventing chronic diseases: a vital investment. Available from: http://www.who.int/chp/chronic disease_report/en/.

4. International Obesity Task Force. Demands action on childhood obesity crisis. [Cited 2011 Jan 27]; Available from: http://www.chw. edu.au/prof/services/chism/iotf_press_release.pdf.

5. Bray GA, Bouchard C. Handbook of obesity: etiology and pathophysiology. 2nd ed. (2004). (2nd ed., pp. 15-200). Basel Dekker: New York.

6. Omolola Ayoola, Kara Ebersole, Olayemi O Omotade, Bamidele O Tayo, William R Brieger, Kabiru Salami et al. Relative height and weight among children and adolescents of rural south-western Nigeria. Ann Hum Biol. 2009; 36(4): 388-399. doi: 10.1080/03014460902835606

7. Ben-Bassey UP, Oduwole AO, Ogundipe 00. Prevalence of overweight and obesity in Eti-Osa LGA, Lagos, Nigeria. Obes Rev. 2007;8(6):475-9.

8. Victor OA, Maxwell UA, Wilfred ON. Soft Drink Consumption and Overweight/Obesity among Nigerian Adolescents. 2008; 3:191-6.

9. Bozić-Krstić VS, Pavlica TM, Rakić RS. Body height and weight of children in Novi Sad. Ann Hum Biol. 2004; 31(3):356-63.

10.Al-Sendi AM, Shetty P, Musaiger AO. Anthropometric and Body Composition Indicators of Bahraini Adolescents. Ann Hum Biol. 2003; 30(4):367-379.

11. Mantsena M, Monyeki KD, Toriola AL. Sex differences in percentage body fat of Ellisras children. Journal of Human Movement Studies. 2002; 43:443-454.

12. Bénéfice E, Ndiaye G. Relationship between anthropometry, cardiorespiratory fitness indices and physical activity levels in different age and sex groups in rural Senegal (West Africa). Ann Hum Biol. 2005; 32(4):366-382.

13. Wickramasinghe VP, Cleghorn GJ, Edmiston KA, Murphy AJ, Abbott RA, Davies PS. Validity of BMI as a measure of obesity in Australian white Caucasian and Australian Sri Lankan children. Ann Hum Biol. 2005; 32(1):60-71.

14. Monyeki MA, Koppes LL, Kemper HC, Monyeki KD, Toriola AL, Pienaar $\mathrm{AE}$ et al. Body composition and physical fitness of under-nourished South African rural primary school children. Eur J Clin Nutr. 2005; 59(7):877-83

15. Cole TJ, Bellizzi MC, Flegal KM, Dietz WH. Establishing a standard definition for child overweight and obesity worldwide: International survey. BMJ. 2000; 320(7244):1240-3

16. Pawloski LR, Moore JB, Lumbi L, Rodriguez CP. A cross sectional examination of growth indicators from Nicaraguan adolescent 
girls: a comparison of anthropometric data from their Guatemalan counterparts. Ann Hum Biol. 2004; 31(6):647-59.

17. Klein-Platat C, Oujaa M, Wagner A, Haan MC, Arveiler D, Schlienger JL et al. Physical activity is inversely related to waist circumference in 12-year-old French adolescents. Int J Obes (Lond). 2005; 29(1):9-14.

18. Fink B, Neave N, Manning JT. Second to fourth digit ratio, body mass index, waist-to-hip ratio, and waist-to-chest ratio: their relationships in heterosexual men and women. Ann Hum Biol. 2003; 30(6):728-38. 